\title{
TRANSNATIONALISM AND TRANSNATIONAL ISLAM IN INDONESIA WITH SPECIAL EMPHASIS ON PAPUA
}

\author{
Ridwan \\ Centre for Muslim States and Societies (CMSS,)The University of Western Australia \\ (UWA), Australia \\ $<$ ridwan.ridwan@research.uwa.edu.au>
}

\begin{abstract}
Papua has experienced the threat of communal harmony between Christians and Muslims regarding the transnational Islam advent in Papua. The Tolikara Incident in 2015 and the latest one the banning of building the minaret of the Al-Aqsha Mosque in Sentani in 2018, to a certain degree, were part of transnational Islam influence in the region with a majority non-Muslim population. The presence of transnational Islam cannot be separated with the emergence of the public sphere in the country after the demise of the Suharto regime in 1998. This paper will explore transnational Islam in Papua by reviewing previous study and discourse on transnational Islam in Indonesia. At the outset, the author will delve literature review on transnationalism and transnational Islam globally. Afterward, it will discuss the presence of transnational Islam, especially Salafi of Jafar Umar Thalib (JUT) in Jayapura and Keerom that has created tension and hostilities within Muslims communities, as well as toward non-Muslim. No doubt, Salafi faction of JUT has tried to promulgate or disseminate radical Islamic teaching through dakwah (propagation) and other activities that threaten Papua Land of Peace (Papua Tanah Damai). As a result, their presence has gotten resistance from some Islamic mass organisations and non-Muslims.
\end{abstract}

Keywords: Transnationalism, Salafi, Papua Land of Peace, Religious Conflict

\section{Introduction}

A mosque manager (takmir) at Masjid Raya Baiturrahim Jayapura City told me that some Salafi-Wahabi preachers had taught Islamic teachings in the mosque. Unfortunately, these teachings of Islam have created tension between fellow Muslims. Due to the frequent discussions of bidh'ah (innovations) of other Islamic groups, 
the takmir eventually "expel" them out from the mosque. This story above is heart-shattering and hardly ever publicly discussed.

Furthermore, the above story shows the phenomenon of the presence of transnational Islamic movements in Papua has triggered tensions with other Islamic organizations (and nonMuslims), especially in Jayapura City. This needs to be studied seriously because there is still little study about it. Therefore, this paper will examine the transnational Islamic movement in Papua by taking a case study of Salafi faction a la Jafar Umar Thalib. I will start this paper with a study of Transnational Islamic terms and its brief development in the world and Indonesia.

\section{Discussing Transnationalism and Transnational Islam}

The term transnationalism is not new, but today it is more widely used in the field of social sciences. Randolp Bourne used the term for the first time in his (1916) article "Transnational America," to mean the articulation of his "visionary new form of pluralism" (Nichols, 2009, p. 217), as well as "cosmopolitanism" as part of the study of transnationalism in international relations that focus on border-crossing actors or networks (Malet and Anderson, 2017, p. 4).

Even though, as Masud observes, the phenomenon of transnationalism has existed at least as long as imperialism, Piscatori has argued that it is only since the 1970s that theorists of political science and international relations have taken an interest in transnationalism's impact on nation-states: "The obvious common supposition was that nationstates were the decisive components of international affairs" (Piscatori cited in Masud 2000, p. xiv).

In the early 1970s, Keohane and Nye (1971) drew attention to the new processes that were resulting in multidirectional linkages across state boundaries. In the early 1990s, the term transnationalism was introduced in anthropology, sociology and cultural studies to describe phenomena associated with global transformation occurring around the world (Vertovec, 2003, 2009).

The increased interest in transnationalism as a topic of study has been tracked by Gustavo Cano (2005). Cano examined the Social Science Abstract Database and found that almost two-thirds of the articles that mentioned "transnationalism" or "transnational" were published between 1998 and 2003. The expansion of the study of transnationalism coincides with the increased study of globalisation (Vertovec, 2009, p. 2). Stiglitz (2002, p. 9) defines globalisation as "the closer integration of the countries and peoples of the world which has been brought about by the enormous reduction of costs of transportation 
and communication, and the breaking down of artificial barriers to the flows of goods, services, capital, knowledge, and (to a lesser extent) people across borders". In defining transnationalism, Keohane and Nye (2000) emphasize the terms "interdependence", "globalisation," and "globalism". Interdependence and globalization refer to "an increased sense of vulnerability to distant causes" (P.105). Meanwhile, globalism means "a state of the world involving networks of interdependence at multicontinental distances" (p. 105).

In a similar vein, Hannerz (2000) emphasised a distinction between globalisation and transnationalism, pointing out that the latter refers to actors who are individuals, groups, movements, corporations, rather than states as corporate actors as in the case of globalisation. However, when the processes of globalisation evolve and deepen, "transnationalism" provides a good explanation of world politics carried out by an increasingly wide range of non-governmental social forces organised across sovereign boundaries (Mandaville 2010). In the same vein, Roudometoft (2005, p. 113) argues that transnationalism involves "several layers ranging from the construction of transnational spaces to the formation of transnational communities".

By recognising that transnationalism has a broad meaning, I chose transnationalism in this paper referring to "communities of outlook that include persons and organisations that share common world views, purposes, interests, and practices which they communicate and act across national borders and jurisdictions" (Juergensmeyer, 2005, p. 193). So, the definition is a cultural other than a political definition of transnationalism. In this context, transnationalism is applied to religion as well.

However, studies on transnationalism have not devoted much attention to religious phenomena in political science and international relations. James (2017) noted that transnational studies scholars have generally ignored the role of religious organisations. These studies mainly focused on economic globalisation, political processes, migration issues, terrorism, violence, organized crime and culture. Thus the study of religious movements in the context of transnationalism and consequently on international relations has been somewhat confused because religion and international relations are based on two different assumptions. James (2017, p. 8-9) maintains, "First, Western modernity is premised on the understanding that the world of government and international relations is basically a secular one; second, religion has always had a universalistic tendency to operate beyond national borders". This is probably because the international relations literature dealing with transnational linkages and 
penetration mainly focuses on political and economic security (Haynes 2001, p. 146).

According to Yasmeen (2005, p. 45), study of International relations has ignored the role of religion because since the end of World War II, the dominant approach in the discipline, that is realist paradigm approach had prioritised national interests between the state and political entities. In this regard, religion and culture have no place in world politics. The rise of neo-liberal ideas in the late 1970s, which recognised the relationship of transnationalism between state and society did not change the situation, where religion still has no a place in the discipline of international politics.

\section{Transnationalism and Religion}

Scholarship on transnational religion can be traced back to the late 1990s. Rudolf and Piscatori (1997, p. 1) observe: "Religious communities are among the oldest of the transnationals: Sufi orders, Catholic missionaries, and Buddhist monks carried words and praxis across vast spaces before those places became nation states. Such religious travellers were versions of civil society playing their roles across the borders".

To date, studies of transnational religions have been undertaken by many scholars (Hayness 2001; Werbner 2003; Levitt 2004; Sing 2013; Mensah et al 2013; Juergensmeyer, 2003). Haynes (2001) argues that
Islam and Christianity are examples of transnational religious communities, both of which existed before the emergence of secular states. Christianity and Islam grew as world religions that developed throughout the world because of colonisation, conquest and the growth of worldwide trade.

In a similar vein, Werbner (2003, p. 897) showed that religious movements have never been constrained by international boundaries, by arguing "Sufism and Christianity spread as proselytizing religions, preceding as well as following Muslim and European imperial expansion into Asia and Africa". According to Juergensmeyer (2003, pp. 7-8), "they are 'religions of expansion' despite their geographical and cultural roots being in one locality". This reemerged as politically important from the late 20 century, invigorated by globalization and the accompanying communication revolution.

Studies of transnationalism and religions have developed in many regions and are not limited to Islam and Christianity, as explained below. Transnational religions in the United States related to immigration have been studied extensively by scholars such as Ebaugh (2004) and Levitt (2004). Ebaugh describes transnational religious ties between immigrants in six American religious congregations in Boston. Levitt (2004, p. 2-3) also discusses patterns of transnational religious organisations. 
Some scholars (Sing 2013; Kitiarsa 2010; Jaffrelot and Therwath 2007; Roniger 2010) have studied religious transnationalism in Judaism, Hinduism, Buddhism and Sikhism. Roniger (2010) examines the impact of transnationalism to Jewish identification and identities. He indicates that transnational factors have maintained a presence in Latin American Jewish life since the establishment of the State of Israel, the period of the Cold War and into the contemporary world. Jaffrelot and Therwath (2007), using the example of the Hindu nationalist movement, argue that there are the implications of political entrepreneurs in the country of origin and the instrumental dimension of long-distance nationalism. Similarly, Kitiarsa (2010) maintains that Buddhism, like other world religions, is a transnational religion, because "the transnationalization of Thai Buddhism since the late twentieth century has emerged out of global cultural junctures, where missionary intent and monastic networks have joined forces" (p.109).

According to Haynes (2009) some transnational religious actors helped to create international order. For instance, the Roman Catholic Church from the 1980s, by using a liberation theology, encouraged authoritarian regimes to democratize in Latin America and parts of Central and Eastern Europe and Africa. Additionally, the Organization of the Islamic Conference (OIC) played a role in helping to promote dialogue and cooperation between Muslim and Western governments.

However, some transnational religious actors, such as al-Qaeda and Lashkar-e-Taiba have threatened international order (Haynes 2012). The impact of religious transnationalism on international order has attracted attention in the post 9/11 era (Snyder, 2011; Ress, 2011; Sandler, 2004; Yasmeen, 2005). There is growing acknowledgment that the study of religion, including transnational Islam, occupies an important place in international relations. The Bali Bombing in 2002, the Madrid Bombing in 2004 and more recent attacks in Paris, Barcelona, Belgium and London add to this realization. This is reflected in the literature published on transnational Islam and its political implications.

\section{Transnational Islam}

The term 'transnational Islam', according to Bowen (2004, p. 880) refers to three phenomena, namely, demographic movements, transnational religious institutions, and the field of Islamic reference and debate. In the first phenomenon, transnational Islam can be defined as 'Muslims may move across national borders for social and economic reasons' (p.880). The second phenomenon of transnational Islam has meant that 'some Muslims belong to religious institutions that either promote cross-national movements as part of their religious practices or encompass and promote cross-national 
communication within their religious hierarchy' (p. 881). Then, the third phenomenon of transnational Islam is more focused on "the creation of networks, conferences and increasingly formalized institutions for systematic reflection among scholars' (p.882). The last two phenomena are related to each other due to the movement of religious institutions involving the transfer of ideas.

Slightly differently, Grillo (2004, p. 865) defines the three types of transnational Islam: Transnational Islam=Islam within transnational circuits, Transnational Islam=Islam within a bi-national/plurinational framework, and Transnational Islam=the umma. An example of the first type includes Muslim immigrants to Italy and France from West Africa (Mali, Mauritania and Senegal). They work in both countries and maintain religious ties in West Africa. Then, the second type refers to how "Those living and working abroad are also bound (legally, economically, politically) by the circumstances of two nation-states: where they reside ('here', France and Italy), and whence they came ('there', Senegal, Mali, Mauritania)" (p. 865).

It is not surprising that the transnational Islamic practices are embedded in network relations between migrant setting and departed homeland. Muslim people and organisations send money back to fund mosques, schools or charity work in their countries of origin. In this regard, Schmidt (2005) used the term diasporic to describe religious activities that maintain network ties between migrants and their homeland.

Meanwhile, the third type, according to Grillo (2004) transnational Islam as the umma, means transnational Islam goes beyond a particular migration circuit or diaspora towards the imagined community of Muslims at large, either within one society or across many (p. 865). In this sense, transnational Islam is an extension of the umma, a term connected with the imagined Islamic community (Mandaville, 2001). The umma in some ways is an imagined community, but it also exists in reality. Allievi (2003) showed that some Turkish mosques in Germany, Switzerland and France have assisted needy Turks in Italy to purchase an apartment for their prayers, which then became the first Turkish mosque in Italy. Another example is internal solidarity amongst Muslims in the event of conflicts, as in Bosnia or Chechnya, not to mention Palestine. In this sense, the umma works as a framework to maintain religious unity and accommodate the cultural diversities of believers. In addition, the umma is very much in tune with contemporary globalisation trends, as well as becoming an inherent source of political instability and unrest in the modern Muslim world (Hassan, 2006).

With its expansion, globalisation 
necessitates “deterritorialisation”. According to Appadurai (1996), globalisation involves increasing deterritorialisation of global flows. In short, Appadurai's notion of deterritorialisation is based on the crossing of territorial boundaries, and suggests that globalization is tied to geographical movement. In this case, globalisation had created the deterritorialisation of Islam (Roy 2004, p. 18). Roy introduced the term "Globalized Islam" as a new trend of Islam that is individualized, uprooted from social and cultural contexts and transnational. In other words, the main idea of this argument is that some Muslims in Europe have lost their links to the original culture of the first generation or no longer diasporic.

Recently, there is an intimate and direct link between globalisation and the rise and development of Islamic transnational networks. Münster (2013) mentions that the presence of transnational Islamic groups has some kind of network structure; HizbutTahrir, Muslim Brotherhood, Fethullah Gülen movement, and others suggest that globalization facilitates the formation of organized transnational groups. For instance, Mohamed Osman (2010) mentions that Hizbut-Tahrir Indonesia (HTI) has links with other Hizbut-Tahrir in other parts of Southeast Asia, such as Malaysia and Singapore. Similarly, Haynes (2009) maintains that globalization provides links between state and non-state actors; thereby religious actors are able to spread their messages beyond borders. In addition to that, Wajdi (2015) discusses one of the lesser known Turkish transnational piety renewal movements that have recently reached Indonesia: the Süleymancis, founded there in the form of an organisation called the United Islamic Cultural Centre of Indonesia (UICCI). This provides an example of how a Turkish Muslim transnational organisation comes to project itself into a new cultural environment (a nonTurkish diaspora context) and adapts to that new context.

\section{Transnational Islam in Indonesia}

Studies on Islam and politics in Indonesia, including radical Islam, developed rapidly after the demise of the Suharto regime's New Order in 1998 (van Bruinessen, 2002). Mubarak (2008) shows that the New Order did not tolerate radical Islamic groups with dreams of building an Islamic state. The emergence of political liberalization in the Reform Era (1998 onward) paved the way for the emergence of radical Islamic groups that had lain dormant during the New Order Era.

Basically, two types of radical Islamic groups emerged during this post 1998 era. First were the open and visible organisations. These movements are easily identified because their founders, members and centres for activities are transparent. In addition, 
they recruit membership openly. This category of open groups includes those that emerged from Indonesia and those that are affiliated with transnational Islam in the Middle East. Home grown groups, include Laskar Jihad Forum Komunikasi Ahlus-Sunnah wal-Jama'ah (LJ-FKAWJ), Front Pembela Islam (FPI), Majelis Mujahidin Indonesia (MMI), and other small radical groups. Those with Middle Eastern ties include Jama'ah Ikhwanul Muslimin (JAMI) affiliated with Ikhwanul Muslimin (Muslim Brotherhood) in Egypt, and Hizbut-Tahrir Indonesia (HTI) a branch of Hizbut-Tahrir, created by Syaikh Taqiyuddin Nahbani in Jerusalem in 1953. The second category consists of closed or underground organisations. These groups are difficult to identify and they recruit membership secretly. Jamaah Islamiyah is included in this category.

Those movements above seem have no relationship with moderate Islamic groups, such as Muhammadiyah and Nahdhatul Ulama (NU). According to Wahid (2009), the radical Islamic groups or transnational Islamic actors have no connections to mainstream Islamic mass organisations in Indonesia such as Muhammadiyah and NU. The radical groups, then, including their political wings, have agendas that differ quite sharply from both mainstream Islamic mass organisations (Rahmat, 2017).

In Indonesia the use of the term transnational Islam emerged in the late 2000s. The term found its momentum when there was active promulgation of anti-democratic rhetoric by some Islamic groups, in particular HTI. A book Ilusi Negara Islam (Illusion of Islamic State) made the term transnational Islam more popular (Wahid, 2009). The book discusses how Wahabbi groups have operated and infiltrated mosques, hospitals and schools belonging to NU and Muhammadiyah in Java, Indonesia. In addition, it reveals that Tarbiyah Jemaah created the Islamist Prosperous Justice Party (Partai Keadilan Sejahtera, PKS) in Indonesia and how it inherited the ideology of Ikhwanul Muslimin from Egypt. Similarly, Rahmat $(2005,2017)$ examined the influence of the ideology of PKS based on Ikhwanul Muslimin, from college mosques to the legislature in Indonesia. Al-Makassary (2013) wrote on the infiltration of transnational Islam in mosques located in the government offices in Jakarta and its surroundings.

Some scholars have studied transnationalism that has a relationship with Salafi-Wahhabi groups in Indonesia (Hasan, 2005; Desker, 2002; Jahroni, 2015; Iqbal, 2016 and Chaplin, 2018). Generally, those studies tell us about the emergence of Salafism in Indonesia, its dynamics and its implications for religious intolerance, mainly in Java. Desker (2002) maintains that Jemaah Islamiyah, Front Pembela Islam (FPI) 
and Laskar Jihad exemplify the extreme manifestation of the Salafi-Wahhabi in Indonesia all of which justify violence against enemies of Islam. These groups identify themselves as Salafi and promulgate a utopian vision, the creation of a new caliphate or Islamic states through revolutionary violence. The presence of these groups challenged moderate Islamic organisations, such as Muhammadiyah and NU.

Following the typology of Mandaville, as mentioned above, the rest of this section briefly describes three transnational Islamic actors in Indonesia that belong to the category of 'deterritorialised' radical groups: khilafists and Salafi-jihadis, namely, Jemaah Tarbiyah, Salafi groups and Hizbut Tahrir Indonesia (HTI). Here, the author only present the Salafi Wahhabi groups in the country.

\section{Salafi-Wahabbi Groups}

One of the transnational Islamic actors in Indonesia is Salafi Jemaah. It is more appropriate to call them 'jamaahjamaah Salafiyun' (Salafi groups), because Salafi never becomes one group. Historically, there is no official institution that unites Salafiyun. In some countries, there are some factions of Salafi, such as Jama'ah Anshar AsSunnah Al-Muhammadiyah in Egypt and Sudan or Jam 'iyyah Ihya' At-Turats Al-Islami in Kuwait, or Laskar Jihad (Jihad Brigade) of Jafar Umar Thalib in Indonesia (Hasan, 2007, 2018).

In the contemporary Islamic movement of the Middle East, "Salafiyun" is a new term, and it is not easy to identify when it begins. Salafi is not a mazhab (a school of Islamic thought) such as Mazhab Hanafi; neither is it an organisation like the Islamic Brotherhood in Egypt. Instead, it is a spirit that has spread to the Islamic world since the period of Tabi' in (...) and it was well-known as "Al-Salaf" or "Ahl Al-Atsar" that challenged "Ahl Al-Ra' yi" and "AlMutashawwif". The salafi is called as "Ahlul Hadits", or the followers of Ahmad bin Hanbal, as opponents of Ahlul kalam in aqidah (creed), and Ahl ar'Rayi in figh (jurisprudence).

Shaikh Al-Islam Ibn Taimiyya and his followers were the most active proponents in spreading, maintaining and creating opinions, as well as explaining salafi teachings in aqidah (creeds), fiqh (jurisprudence) or akhlaq (ethics). Imam Abdullah ibn al-Qayyim was one of his best students. Both Shaikhs wrote a rich literature for Salafi in their period, as well as for the interest of Salafi followers after them.

In the contemporary era, Salafi was reborn through the reformer of Salafiyah in Saudi Arabia: Shaikh Muhammad ibn Abdul Wahhab. This Salafi faction has a distinct character that is to fight all forms of syirk and khurafat. Ibn al-Wahhab wanted to free umma from bid'ah where many people did not follow Salafi path. In addition, Ibn al-Wahhab denied the interpretation of 
Qur'anic verses or hadits (the Prophet sayings) regarding the attributes of Allah. This was the main root of Salafi groups.

Ibn al-Wahhab differed from Ibn Taymiyah and Ibn Al-Qayyim in understanding shari'ah. Ibn al-Wahhab inherited previous people's tendency to interpret shari'ah literally, by denying discussion regarding various goals, meanings and reasons behind the shari'a laws. Hence, salafi groups denied it, Abu Fadhal said that Salafi and Wahhabi are the same movement. In the 18th Century, Muhammad ibn Abdul Wahhab created Wahhabism in Jazirah Arabia. He attempted to purify Islam from syirk, bid'ah and khurafat, thereby he acknowledged had infiltrated into the religion. He applied a strict literal approach that made texts as the only source of valid authority and was extremely hostile to intellectualism, mysticism, and all other sects in Islam.

At the end of 18th Century, the Saud family were incorporated into the Wahabbi movement and rebelled toward Utsmaniyah domination in Jazirah Arabia. This rebellion was filled with bloodshed because Wahhabi people slaughtered Muslims and non-Muslims without discrimination. At that time, the popular ulemas were Hanafi bin Abidin and Malik Al-Sawi called Wahabbi as modern khawarij, as well as condemned its fanaticism and intolerance. In 1818, Muhammad Ali lead an army to extinguish the rebellion and it seems
Wahhabism was doomed as a peripheral historical event that did not have a strong influence on Islamic theology.

In the early 20th century, Abdul Azis bin Saud revived salafiyah's doctrine by joining Ihkwan, a militant rebellion, in the beginning of the formation of Saudi Arabia. Wahhabism was a doctrine of limited influence until the middle of 1970s, when a large increase in the price of oil, combined with an aggressive approach by the Saudis to spread Wahhabism had resulted a dramatic effect on the spread of Wahhabism in the Islamic world.

Wahhabism did not spread its doctrines as an Islamic thought or specific orientation in Islam, but called itself "the Straight Path" of Islam. Wahhabism consistently applied a literal approach to understanding Islam and hence claimed an authenticity that was believed when Islamic identity was contested. In addition, the advocates of Wahhabism rejected being called followers of any Muslim figures, including Ibn al-Wahhab. They emphasized that they only followed Salaf al-Shalih (the Prophet and his companions) and hence, the Wahhabi group was able to use the category of Salafism.

As a movement in the early 20th century, the term Salafi was used with a liberal orientation by Al-Afghani, Muhammad Abduh and Rasyid Ridha. They used it to respond to modernity's demands when they called for a return 
to al-Qur'an and Sunnah and applied it in interpretation of the texts. The main driver of this Salafiyah movement was Muhammad Rasyid Ridha (the founder of Al-Manar magazine). He was influenced by Muhammad Abduh who had an open attitude toward western ideas. This was the reason that Rasyid Ridha was not acknowledged by modern Salafiyun. In other words, they don't follow Rasyid Ridha's reformation, although he was the true leader of the enlightenment of Salafiyah.

In the early 1970s, Wahhabi had transformed Salafism from a liberal modern theology into a literalist, puritan and conservative theology. The rise in fuel prices in 1975 made Arab Saudi had access to a lot of money that allowed them to promoted global Wahhabism. Salafi-Wahhabi is the first group calling for 'deculturation' and 'derationalisation' in Islamic ideas and movements. They called for Islamic purification through a return to al-Qur'an and Sunnah. They implemented an agenda to tackle local culture that had been accommodated to by Muslims, and to the spiritualist tradition of mysticism. At the same time, Salafi prohibited using rationalism and preferred literal interpretation of al-Qur'an and Sunnah (prophet deeds). In addition, they even assumed that the classic ulemas's books had been written by humans and therefore fouled the pristine Islam that had come from Allah. The contemporary Salafiyah in the Middle East consists of five groups (al-Qardhawi 2003). The first group, 'Salafiyyun Sururiyyun' referred to Muhammad Syurur Zen Al-Abidin. This group has a political orientation and inherited ideas of the Brotherhood. This Salafi group resisted the presence of the United States and its military intervention in Gulf War II. The second group, 'Salafiyun Al-Albaniyun' followed Shaikh AlMuhaddist Nashiruddin Al-Al-Bani. This group resisted mazhab fanaticism and rejected taklid (blindly following without thinking rationally) even for lay people. However, at the same time, this Salafi group blindly followed all opinions of Al-Albani and proclaimed themselves as "the fifth Mazhab". The third group, 'Salafiyun A1-Jamiyun' referred to Shaikh Rabi' Al-Madkhali. This group often blamed and attacked all ulemas and dais with different ideas to them. The fourth group, 'Salafiyun of Shaikh Abdurrahman Abdul Khalik' in Kuwait and the Fifth group 'Salafiyun of Saikh bin Baz and Shaikh Utsaimin' in Arab Saudi have not yet established themselves as an organised Jemaah.

Salafi-Wahhabi movement was promoted in Indonesia in the second half of the 1980s (Hasan 2007; Rahmat 2017). In the 1980s, this movement faced an obstacle because the Suharto regime opposed Islamic groups that were assumed to have had a political agenda, such as establishment of an Islamic state, which was different 
to the regime. In the 1990s, Suharto implemented political accommodation by approaching Islamic groups, including Salafi groups that had an opportunity to disseminate their ideas. The Reformation era (1998 onward) paved the way for Salafi groups to spread their influences in Java and in many cities of Indonesia, including Papua. During this era, Salafi-Wahhabi activists in Indonesia started building Islamic boarding schools based on Salafi ideology and used books written by Salafi figures such as Muhammad Nashiruddin Al-Bani and Bin Baz.

The Salafi movement in Indonesia has attempted to purify Muslim's aqidah. The movement has undertaken campaigns to liberate Muslims from "viruses" that have contaminated pristine Islam, such as tasawwuf, tawasul, rationalism, Shi' ite teaching and many religious practices that were assumed as bid'ah. Hence, the movement problematized and revived the issues that were brought to the fore by puritans groups in the early 20 th Century.

Salafi used three institutions to promote and spread its ideas: Islamic boarding schools, mosques and universities. In order to do this, they received donations from Saudi Arabia and Kuwait. Some notable figures of the salafi movement in Indonesia are Abdul Hakim Abdat, Yasid Jawaz, Abu Nida, Farid Okbah, Ainul Harist, Abu Bakar M. Altway, Ja'far Umar
Thalib and Yusuf Usman Baisa. These figures have worked on spreading salafi ideology through Islamic boarding schools, mosques and book publications (Rahmat 2017).

In its development, Salafi Jemaah in Indonesia was divided into two camps: one group referred to Kuwaiti organisations, such as Abdul Hakim, Yusuf Baisa and Abu Nida, and the other group referred to Saudi organisations, namely, Ja'far Umar Thalib. The divisions occurred because Thalib protested the statement by Yusuf Baisa that in order to spread Salafi a system of organization similar to that of the Ikhwanul Muslimin was required. This should follow the wisdom of Jemaah Tablighi and make Salafiyah as aqidah underpinnings. Another reason was that Yusuf Baisa taught ideas of the figures of Salafi Surruriyun that were close with the Ikhwanul Muslimin. Thalib assessed this as a deviation from pristine Salafi. The peak of hostility occurred when Thalib established Laskar Jihad Ahlus Sunnah walJamaah. In the camp of Yusuf Baisa, Abu Nida and Abdul Hakim assessed the Thalib act as a deviation, because it violated two principles of Salafi Da'wa; JUT had played political games and had been trapped for hizbiyyah because it created a mass organisation. In addition, Laskar Jihad had been involved in communal conflict in the Moluccas and Poso, Indonesia (Hasan 2009, Van Klinken 2007). 
Recently, Salafi transformed itself to move beyond the categorization of Salafi made by Qardhawi. Despite the general tendency of Salafi to be a nonpolitical group, they were assumed to play political games as bid'ah, which have been supported by Saudi Arabia. There are Salafi that have radical ideology, namely, Salafi Jihadis and Salafi Takfiri, both of which have been accused of conducting terrorist acts in the world, including in Indonesia (Rahmat 2017).

Overall, the Salafi Da'wa movement has spread throughout Indonesia, including to Papua because of the aggressive da'i. In addition, the support of a transnational network with facility and funding will make the Salafi movement stronger and will challenge mainstream moderate Muslims, especially NU and Muhammadiyah as representative organisations for Islam in Indonesia.

\section{Salafi Faction Jafar Umar Thalib in Papua}

On 15 July 2015, the Tolikara incident occurred and drew attention globally and nationally. Some Muslims in Indonesia, without knowing the case comprehensively, were angry and condemned the event. On 20 July 2015, Jafar Umar Thalib (JUT) issued the declaration of Jihad Fisabilillah to Papua. The content of the declaration was firm that is the proclaiming war against the Gereja Injili Di Indonesia
(GIDI) group that attacked the Tolikara Muslims. In addition, JUT claimed the Government of Indonesia as a kafir (infidel) government (Al-Makassary, 2017).

Two months after the Incident, JUT ordered two of his followers going to Papua to look for land to set up pesantren (Islamic Boarding School). In October 2015, both arrived and found a rented house in Koya Barat, Muaratami District, Jayapura. The district is located near to the border of Papua New Guinea. Koya Barat can be reached by bus or car about an hour from Jayapura. For years, Muslims transmigrants from Jawa have lived with indegenous Papuan Christians in communal harmony.

Muslim community accepted JUT's member after staying two months in Koya Barat, Muaratami District in Jayaputra city. Fauzi, one of the members, had given sermons frequently in mosque Al Muhajirin including eight mushallas. As a result, many Muslims were attracted with Fauzi's Islamic teaching. After settling in Koya, Fauzi contacted JUT and in November 2015, JUT and his 40 santris (disciples) came secretly.

What were the motives of JUT and his disciples to come to Papua? In the meeting with a team created by the Mayor of Jayapura, JUT said his presence was to establish a pesantren because morals of the Indonesian nation were broken and it will be healed from 
Papua. JUT did not mention the Tolikara incident as a main reason that brought him to come to Papua. In addition, JUT stated "The Mollucas conflict was his past and now he wanted to preach to Indonesian people through education from Papua".

However, the Tolikara Incident was an obvious reason for JUT to come to Papua. We noted, in responding to the Tolikara incident, JUT echoed the declaration of Jihad Fisabillillah to Papua, as mentioned above. In this sense, Abu Yahya, a member of JUT, justified this reason by saying that JUT was "seeing" Papua as a place for jihad because of the Tolikara incident. Fortunately, the Indonesian Government handled the incident quickly. In this regard, Abu Yahya said "If the Tolikara incident was not resolved, JUT had given command to 50 members for doing Jihad to burn entire churches in Papua".

JUT started preaching Islamic ideas based on Wahhabi in Keerom and its surrounding. Usually, he gives sermons after Subuh prayers in some mosques, espeacially in Masjid AlMuhajirin Koya Barat. Principally, JUT's teachings are based on Wahhabi teachings. In the same vein, Hasan (2009) stated that the education system in JUT's pesantren in Yogyakarta and some pesantren affiliated with JUT is conservative, thereby the educators deny teachings and activities that have been contaminated by Western culture and challenged traditional religious corpus. The understanding of the Wahhabis became the foundations of the santri to learn any subject in Islam, including fiqh, hadits and da'wa.

JUT and his disciples not only teach Islamic ideas based on Wahhabi understanding, but also distribute books entitled Jihad Fisabilillah and The Black Notes of Shia Religion and videos which were related to the Wahhabi's teaching to Muslims living in Koya Barat and its surroundings. According to my informant, JUT had built up his prestige through teaching and distributing his books. Hence, some Muslims in Koya perceived him as a hero for Muslims in Papua.

On 11 June 2017, HTI held the Nuzulul Quran at mosque Al Muhajirin, Koya Barat, JUT and Hizbut Tharir Indonesia (HTI) Chapter Papua were collaborated. On that occasion, JUT delivered a speech which was not only a normative one but also a controversial one. For example, JUT said "Muslims are forbidden to make contact like riding a motorcycle or chatting in tandem with adult women who are not muhrim, because it is illegal". Some of the teachings conveyed in the open discussion will invite tension not only among the Muslims, but also the nonMuslims who are the majority in Papua. Principally, the main idea of JUT's arrival is to set up a pesantren. In doing so, since staying in Koya Barat, JUT and his disciples were busy looking 
for a suitable place to realize the idea in the Keerom regency that shares a border with Papua New Guinea. This region has many Muslim transmigrants especially from Java that work for trading, farming and fishing. Now, the percentage between Muslims and Papuan Christians is 40:60. But my informant said "In reality Muslims are more in number than Christians".

In the beginning, JUT planned to buy land in Arso 1 but he faced obstacles from the land owner and the leader of the ethnic tribe (ondoafi). Finally, JUT bought 26.5 hectares in Arso 14. He will be dividing the land for building of the Pesantren on five hectares; for agriculture, four hectares; for plantations, ten hectares; and for farms, seven and a half hectares. In addition, JUT bought 200 hectares that will be used for sugar cane farming. In this regard, my informant said JUT bought land which was costly. $\mathrm{He}$ added, "We do not know about the sources of the funds. We heard JUT got it from the political elite in Jakarta. But this needs more clarification". In addition, the purpose of buying the land also was misused by JUT. A senior staff at the local government in Jayapura, Evert Meraudje, said "JUT bought land for farming and he changed it for building the pesantren".

JUT planned, after establishing pesantren in Arso 14, to establish 20 pesantrens in Papua. According to my informant, "This is based on JUT's experience in the Afghanistan war against the Soviet Union. Starving for logistical support was the cause of the defeat of the Soviet army. So, JUT will establish pesantren with the concept of agriculture, plantation and animal husbandry to meet their own logistical needs. So, the incident that afflicted the Soviet troops in Afghanistan did not happen". In this regard, it seems that JUT is preparing for a conflict between Muslims and Christians in the future.

To manage the building of the pesantren, JUT chose his son, Amir Thalib. Four santris and two craftsmen have assisted Amir. The name of the pesantren is Ihya Us Sunnah, the same name of JUT's pesantren in Yogyakarta. However, in establishing his first pesantren in Keerom, JUT has gotten much resistance from Muslim communities.

Participant's reactions in Majelis Ulama Indonesia (Indonesia Ulama Council) meeting in Jayapura with JUT in 2015 were varied. A young Muslim while trembling delivered his strong protest by saying JUT's arrival will bring worry within religious communities in Papua. Fadhal Alhamid, the name of the young Muslim, added "An attempt to maintain peace in Papua will be harder if JUT operates in Papua". Another young Muslim told his story about his experience living in his society at the village of Walesi, Wamena. He said, some Christians and Muslims live in the same house 
together. Some participants argued that they do not want JUT's arrival to exacerbate good communications amongst interfaith and family relationship. In short, all participants agreed to reject JUT's planning to set up his pesantren (Al-Makassary, 2017).

Participant's rejection of JUT's arrival were based on some reasons: First, JUT's track record was filled with violence and intolerant acts in Ambon and Yogyakarta. Muslims in Papua do not want religious conflict to happen in Papua such as Moluccas conflict that involved JUT and his Laskar Jihad. Second, communal harmony amongst Muslim groups in Papua is good without an attempt to call them infidels or blame other groups. Third, JUT's attitude in his declaration "War against pluralism" is denying of Sunatullah (Allah's will) and it will create tension with non-Muslims in Papua.

In the same vein, the chairman of MUI Papua, Uztad Al-Payage, said, "We have seen that the way JUT is doing his da'wa is not relevant with the situation in Papua. Here people are diverse and do not blame each other. In one family there can be many religions. Hence JUT's method in da'wa is not relevant".

Overall, considering all suggestions from participants in the meeting, MUI Papua released the recommendation that JUT needs to leave Papua. Muslim groups in Papua can maintain their religion without intervention of groups that tended to claim they were more innocent and more truthful than others like JUT's teachings.

\section{Conclusion}

In the midst of the failure of the nation-state, with which transnational Islam are often seen as "enemies of the state", due to some of their actors promote Islamic caliphate or Islamic state. Transnational Islamic actors are very diverse, from those who pursue jihadist paths such as al-Qaida, Salafi jihadists to piety, khilfatis like Hizbut Tharir and apolitism like Jemaah Tabligh. In Indonesia the term transnational Islam emerged in the late 1970s and thereafter many studies have been published.

In Papua, the study of transnational Islam is still limited. Based on the above discussion, the presence of JUT and his disciples in Papua (Jayapura, Sentani and Keerom), had sparked tension within Muslims and non-Muslims. In particular, a plan to establish pesantren as a site of preaching Wahhabi Salafi triggered strong protest from MUI, Papuan Christians and Islamic mass organisations. In reality, JUT and his disciples are enduring in Keerom and teaching their Islamic ideas.

The current situation shows that JUT got many supporters from some Muslims and the local government elite and the Chief of Police in Keerom. My informant told me that JUT started working again on building 
the construction of his pesantren. He said "A lot of materials and heavy vehicles are in the construction site". At the same time, the third letter by the former Major of Keerom was not applied to JUT. Hence, JUT's presence and his endurance to preach his radical Islamic ideas as perceived, will destroy the vision of "Papua Land of Peace", thereby religious leaders and society in Papua agreed to maintain communal harmony.

\section{Acknowledgement:}

This paper is part of my thesis "Transnational Islam in Indonesia: A Study of Hizbut Tahrir Indonesia in Papua" funded by The Indonesia Endowment Fund for Education (LPDP), an agency under the control of the Indonesian government. []

\section{References}

Al-Makassary, Ridwan dkk 2011 Masjid dan Pembangunan Perdamaian. Jakarta: CSRC.

Al-Makassary, Ridwan 2015 Damai Papua Damai Indonesia. Yogyakarta: Kementrian`Agama Papua.

Al-Makassary, Ridwan 2016 Dialog dan Radikalisme Agama di Tanah Papua. Yogyakarta: FKUB Papua.

Al-Makassary, Ridwan, 2017 Insiden Tolkara dan Jafar Umar Thalib: Kontroversi Mushalla yang dibakar dan Drama Jihad di Tanah Papua. Yogyakarta: Kementrian Agama Papua.

Ayoub, M. 2008 The Many Faces of Political Islam Religion and Politics in the Muslim World. Michigan: University of Michigan.

Eickelman, D. F. 1997 Trans-state Islam and Security. In S. H. Piscatori (Ed.), Transnational Religion and Fading States (pp. 27-41) Colorado: Westview Press.

Esposito, J. L. 1999 The Islamic Threat. Oxford: Oxford University Press.

Hasan, Noorhaidi, 2006 Laskar Jihad: Islam, Militansi, Dan Pencarian Identitas Di Indonesia Pasca Orde Baru, Jakarta: LP3ES.

Hayness, J. 2012 Religious Transnational Actors and Soft Power. Farnham: Ashgate Publishing Limited.

Hegland, R. T. (Ed.). 1987 Religious Resurgence Contemporary Cases in Islam, Christianity and Judaism. New York: Sycrausse University Press.

Jones, Sydney, INDONESIA: COMMUNAL TENSIONS IN PAPUA Asia Report N 154 16 June 2008. Diakses pada 5 November 2017 dalam http://www.genocidewatch.org/ images/Indonesia_08_06_16_Communal_Tensions_in_Papua.pdf

Juergensmeyer, M. 2008. Global Rebellion Religious Challenges to the Secular State, From Chritian Militias to Al-Qaeda. California: University of California Press.

Kepel, G. 2004 The war for Muslim Minds. Massachussets: Harvard.

Mandaville, P. 2001 Transnational Muslim Politics Reimagining the Umma. In Mandavile, Transnational Muslim Politics Reimagining the Umma. New York: Routledge. 
Piscatori, S. H. (Ed.)1997 Transnational Religion and Fading States. Colorado: Westview Press.

Ress, J. A. 2011 Religion in International Politics and Development-The World Bank and Faith Institutions. Cheltenham, UK: Edward Elgar Publishing Limited.

Sandler, J. F. 2004 Bringing Religion Into International Relations New York: Palgrave Macmillan.

Snyder, J. 2011 Religion and International Relations Theory New York: Columbia University Press.

Yasmeen, S. 2005 Islamic Groups and Pakistan's Foreign Policy: Lashkar-E-Thoiba. In Islam and The West Reflections from Australia Sydney: UNSW Press.

Widjojo, Muridan. S, dkk 2010 Papua Road Map: Negotiating the Past, Improving the Present and Securing the Future, Jakarta: Yayasan Obor 